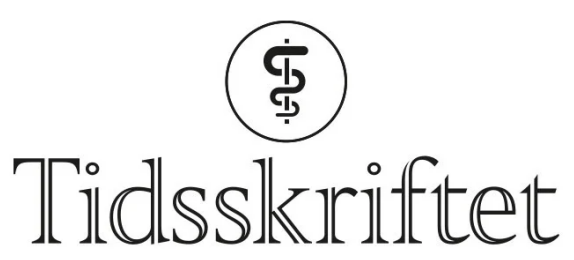

DEN NORSKE LEGEFORENING

\title{
K. Kolnes og B. M. Jåtun svarer
}

\author{
KOMMENTAR \\ KRISTIAN KOLNES \\ kristian.kolnes@gmail.com \\ Kristian Kolnes er overlege. \\ BJØRN MAGNE JÅTUN \\ Ingen av forfatterne har oppgitt noen interessekonflikter.
}

Vi takkar Per Holck for innspelet, og gleder oss over at ein slik framifrå kollega fann interesse i vår artikkel. Dessverre har vi ikkje blitt merksame på Holck sin kommentar før nå. Fleire artiklar gjer greie for skilnaden mellom sebralinjer og Harrislinjer, og nemner det faktum at ein tidvis ser slike sebralinjer også i epifyse og apofyse. Vi har også eksempel frå sistnemnde i eigen praksis. Vi viser til vår referanse 2 i vår artikkel (1), som går djupare inn i denne materien. I artikkelutkastet hadde vi med ein kort passus om Harrislinjer, men blei bedne av fagfelle å anten ta vekk dette, eller gå djupare inn i samanhengen mellom sebralinjer og Harrislinjer. Om vi valde det siste alternativet hadde artikkelen vorte for lang til å få plass i det aktuelle formatet (Medisinen i bilder). Vår agenda med publiseringa var primært å gjere kollegar merksame på dette iaugefallande funnet som kanskje ikkje alle radiologar og barnelegar er familiære med. Funnet er ein normal respons på bisfosfonatbehandling ved osteogenesis imperfecta, og treng soleis ikkje leie til vidare utgreiing.

\section{LITTERATUR}

1. Muderis M, Azzopardi T, Cundy P. Zebra lines of pamidronate therapy in children. J Bone Joint Surg Am 2007; 89: 1511-6. [PubMed][CrossRef]

Publisert: 22. november 2021. Tidsskr Nor Legeforen. DOI: 10.4045/tidsskr.21.0770

(C) Tidsskrift for Den norske legeforening 2023. Lastet ned fra tidsskriftet.no 26. april 2023. 